\title{
Dation In Payment Of The Mortgaged Homestead
}

\author{
Pilar Domínguez-Martínez, Ph.D., University of Castilla-La Mancha, Spain
}

\begin{abstract}
The indebtedness of Spanish households coupled with a marital crisis, requires finding solutions to combine the protection of family interests, mainly of children, housing needs of society and the satisfaction of the creditor's right to credit mortgage crisis when the family faces the mortgage payment that affects the family housing. Also, new laws on regional express recognition of the custody and control of the destiny of the family housing in cases of divorce and separation through formulas such as the sale of the house, let consider the use of dation in payment of the family housing as a way to avoid foreclosure in cases of marital crisis in the context of current economic crisis.
\end{abstract}

Keywords: Family Housing; Mortgage; Dation in Payment; Insolvency; Marital Crisis

\section{INTRODUCTION}

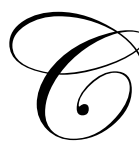

Pompliance or payment of an obligation as well as causing the extinction of debt is the normal purpose for which it was formed. In a situation of insolvency of the debtor and in order to release and satisfaction of the credit claim, the legal system adjudicates certain figures called the "surrogate for compliance," including Article 1175 of Civil Code provides for the transfer of assets called for payment of debts. Occurs when the debtor of a certain obligation towards the creditor / s has reached a state of insolvency as to leave, move the goods of their heritage and give them to your creditors. The borrower gives the lender power of disposal for the realization of their value to cover the loans, fully or partially. The excess value of the goods supplied, once taken its toll belongs to the debtor.

On the contrary there is a subrogation payment criteria, whose basic shape is not regulated by the Civil Code and is very similar to the transfer of assets, is the "foreclosed" "solute pro cesium" is the assignment in return for no payment. Although not explicitly regulated, is mentioned in an article like 1521, 1636 and 1894 Civil Code. That is, do not give the goods to that place value and is charged to the creditor but is making a payment to the good itself. This results in the transfer of ownership to the creditor, although unlike the transfer of goods not requiring the existence of an insolvency of the debtor, or the existence of plurality of creditors against it. At the time of payment is a transformation of the object of the obligation causing the extinction of an obligation regardless of the mismatch value of the asset given the amount of the amount due.

The payment in kind has a long tradition in Roman law known as dati in solutum. In this sense, STS May 24, 1945 reminds us that this was regulated legal figure in the fourth of the Novels of Justinian as an exception to the identity of the payment under the Latin aphorism "alius pro alio invite you credit, non solvi potest. ". This figure is supported by the jurisprudence (SSTS 23 September 2002, 26 June 1993, 8 February 1996, among other). Specifically, the Sentence 1 October 2009 ruling that resembles this figure with the sales contract, though not identified with a contract, the nature bargaining agreement is an obligation and extinct.

In countries like France, Belgium, Germany or the Anglo-Saxon countries take into account the situation of personal and mortgage debt overhang of individuals, when the debtor is in good faith (for reasons which occurred) and the mortgaged property is the residence. It recognizes the "payment in kind", ie legal possibility to cancel the mortgage debt through the delivery of the property mortgaged to the bank. 
However, in our right there is a brake up of the principle of unlimited liability set forth in Article 1911 of the Civil Code, which states: "From the fulfilment of the obligations the debtor responds to all present and future goods."

However this principle, like to stress, disruption of this principle through a novel doctrine contained in the famous Order of the 2nd Section of the Provincial Court of Navarre of 17 December 2010 establishing a system of payment in favors families insolvent. This is a novelty, since it involves a new interpretation of the Mortgage Law, because in the end denies personal responsibility for who requested the loan, limiting the collateral for the loan to property value. This is a way to adopt a view identical to other countries, where the mere return of the property void the credit.

The Court, "the bank itself in the writing of home equity loan and in connection with the property that is subject to auction and was awarded the said bank materially the value by an amount that exceeded the lead loan (...) This being so, is to address the reasons why the judging instance not consider it appropriate in this case continue execution, to understand the value of the property, notwithstanding the outcome of the auction, is sufficient to cover the principal of the claim and even found above that principal. "And in the attempt by the bank to argue that the current value of the property is less than the initial appraisal, the Court reminded the entity of their own responsibility in it: "morally reprehensible is alleged attempt to continue running the loss of value of the estate that served as collateral for the loan, which had not been granted had he not had sufficient value to guarantee the loan, which was set by the bank now performing, or at least accept, being that this loss value is directly attributable to the economic crisis, resulting from the malpractice of the financial system".

In fact, foreclosure is the fact of losing the home for unpaid mortgage. The property goes to auction, and the Code of Civil Procedure (LEC) 1 / 2000 provides that in case of no bidders, the bank can claim the home for $50 \%$ of the value of the new valuation (Art. $670 \mathrm{ECC}$ ). The bank not only keeps the home for a much lower price than the price at which the mortgage was signed, but can claim the remaining debt.

It is true that under Article 1911 of the CC. The mortgage loan in addition to tax the property, the loan is a personal right. If payment, the person responds with all their present and future. However, this is a state of vulnerability, vulnerability of the debtor and his family with a high risk of social exclusion and financial exclusion, making it impossible in practice, the recovery of their civil and economic life.

The case was referred to resolved a dispute between a bank and a customer which the bank had been the floor auction (for below appraised value) and it also required monthly payments on outstanding debt considered. The Court confirmed the lower court decision declaring the refusal to continue the execution, except amounts owed by liquidated costs and interest. Therefore, the delinquent owner has no obligation to continue paying the monthly payments when the value of the property, notwithstanding the outcome of the auction should be sufficient to cover the principal of the debt claimed, or higher.

This will occur when the financial institution has assigned the contract of loan to the mortgaged property worth more than the principal amount guaranteed. In addition the property is awarded to the same bank for an amount significantly lower than the value that had been attributed to the deed.

Notwithstanding the novelty of this solution, test case, this requires that we find ourselves faced with two decisions of the Supreme Court. We hope the Supreme Court decision in favor of this solution, unifying and fundamental role in the defence of consumer and family in the current crisis. decreased property values as a result of the current economic crisis has its root cause in the malpractice system's financial system where financial institutions such as bank have a role, so that somehow the fact unable to recover the amount would be the result of his own performance, understand why it cannot be expected to respond particularly now that decrease in value.

Also referred to Article 3 of the Civil Code, section 1, states that the rules be interpreted as the reality of time that must be applied, based primarily with the spirit and purpose of those, and this obliges us to do this reflection, that it shall not constitute an abuse of law, but is morally reprehensible alleged attempt to continue running the falling value of the property that served as collateral for the loan, which had not been granted had it not 
been sufficient value to guarantee the loan, which was set by the bank now performing, or at least accept, being that the loss of value is directly attributable to the economic crisis, resulting from the malpractice of the financial system, we repeat, even if it can be attributed directly and specifically to the bank (..) does not cease to be a reality that is part of the protagonists of the financial system, and why it is especially painful that the argument which justifies its claim, is based on circumstances that essentially and as they say, has caused great sensation and raised "blisters." (...)".

In short, the need to adapt the legislation on immovable property mortgaged to the surrounding countries, the legal traffic safety for home buyers and borrowers. The current regime violates the principle should be synallagmatic contracts and compliance cannot be left to the discretion of one party. The appraisal would have been the basis for the loan is left to one of the parties, the financial institution. This corresponds to the Auto line of the petition, accepted by Congress to reconsider the particular responsibility of the credit arising after the return of unpaid housing guaranteeing payment. It also implies a clear boost to the normalization of the foreclosed housing rather than judicial enforcement. That is why waiting for the answer jurisprudence; it is singular proposition of law to present to the Bureau of the Congress of Deputies for modification of the Mortgage Law.

This is the proposition of law in lieu of payment of the mortgaged with debt relief, which aims to introduce clear rules and limits, which allow to provide legal certainty in lending to prevent abuses by financial institutions and household indebtedness (Article 1). Noteworthy is the usual reference to family character of the mortgaged delivered as payment in kind. Article 2 states that "Persons having full ownership of a personal or family housing common is mortgaged, may give it in payment to the holder of the mortgage recorded in the Land Registry. The giving in payment unilateral transmit full ownership of the house, and extinguish all outstanding debt secured by mortgage principal, interest, penalties, fees, and any other capacity."

As to how to formalize the payment unilateral "Dacion" Article 3 of that proposition, how could it be otherwise will require a public document, with notification to the holder of the mortgage recorded in the Land Registry. Furthermore and in order to delimit this figure in order to protect the family interest, the housing needs of society and fulfilling the right of the mortgagee's credit crisis when the family faces the mortgage payment that affects on the family home is required to provide an affidavit stating that it is a personal or family living standard.

The effect of extinction will be the giving of the mortgage and the purchase of home ownership by the encumbrance whose access to the Land Registry may take place through the presentation of writing and record. In no case need the consent of the holder or holders of the mortgage to complete the cancellation of the mortgage and registration of housing in favour of the mortgagee (Article 4).

\section{CONCLUSIONS}

The current regime violates the principle should be synallagmatic contracts and compliance cannot be left to the discretion of one party. The appraisal would have been the basis for the loan is left to one of the parties, the financial institution. This is a novelty, since it involves a new interpretation of the Mortgage Law, because in the end denies personal responsibility for who requested the loan, limiting the collateral for the loan to property value. This is a way to adopt a view identical to other countries, where the mere return of the property void the credit. Notwithstanding the novelty of this solution, test case, this requires that we find ourselves faced with two decisions of the Supreme Court.

We hope the Supreme Court decision in favor of this solution, unifying and fundamental role in the defense of consumer and family in the current crisis. decreased property values as a result of the current economic crisis has its root cause in the malpractice system's financial system where financial institutions such as bank have a role, so that somehow the fact unable to recover the amount would be the result of his own performance, understand why it cannot be expected to respond particularly now that decrease in value. However, legal and security issues make it necessary to find alternative solutions. For example, rent with option to buy, greater control of unfair terms of mortgage loans, auctions. In short, greater protection of the insolvent debtor when a natural person. 


\section{AUTHOR INFORMATION}

Pilar Domínguez-Martínez: Assistant Professor of Civil Law at Civil Law Department. Faculty of Social Sciences of Cuenca. University of Castilla-La Mancha (Spain). B.A. in Law-University Autónoma of Madrid (Spain). J.D.- University of Castilla-La Mancha (Spain). Academic Coordinator of Specialized Degree in Domestic Violence. University of Castilla-La Mancha. E-mail: Pilar.Dominguez@uclm.es

Research Interest: Law of Civil Responsibility, Family Law and all sectors of civil law.

\section{REFERENCES}

1. $\quad$ Albaladejo, M (2004): Derecho Civil II. Ed. José María Bosch, Barcelona.

2. $\quad$ Bercovitz, R (2007): Manual de Derecho Civil. Obligaciones. Bercal, Madrid.

3. Diez, L. and Gullón, A. (2002): Sistema de Derecho Civil II, ed. Tecnos, Madrid.

4. $\quad$ Lacruz, J. L.(2002): Elementos de Derecho Civil II, vol. 1 y 2, ed. José María Bosch, Barcelona.

5. Lete, J (2005): Derecho de Obligaciones, vol. I, ed. Aranzadi, Madrid.

6. $\quad$ Lete, J (2006): Derecho de Obligaciones, vol. II, ed. Aranzadi, Madrid.

7. Sánchez, F. J (2008): Curso de Derecho Civil II. Derecho de obligaciones, contratos y responsabilidad por hechos ilícitos, Tirant Lo Blanch, Valencia, 2008. 